\title{
PELATIHAN LEARNING THEORY OF CAREER COUNSELING BAGI GURU BIMBINGAN DAN KONSELING
}

\author{
Evi Winingsih), Eko Darminto ${ }^{2)}$, Wiryo Nuryono ${ }^{3)}$, Ari Khusumadewi ${ }^{4}$, \\ Roby Anggara Handika Putra ${ }^{5)}$ \\ ${ }^{1}$ Bimbingan dan Konseling, Fakultas Ilmu Pendidikan, Universitas Negeri Surabaya \\ 2,3,4,5Fakultas Ilmu Pendidikan, Universitas Negeri Surabaya
}

\begin{abstract}
Abstrak
Pengabdian kepada masyarakat ini bertujuan untuk meningkatkan kompetensi pelayanan guru Bimbingan dan Konseling tingkat SMP di Kota Mojokerto. Peneliti bekerja sama dengan pihak MGBK SMP Kota Mojokerto. Kompetesi yang dilatihkan adalah softskills berupa pemahaman guru Bimbingan dan Konseling tentang Pelayanan di bidang karier yang berorientasi pada pendekatan LTCC. Target yang ingin dicapai setelah pelatihan ini adalah pemahaman yang pada akhirnya akan berpengaruh pada pelayanan konseling di bidang karier. Metode yang digunakan dalam PKM ini adalah melakukan pelatihan kepada guru Bimbingan dan Konseling dalam waktu tertentu. Kompetensi guru Bimbingan dan Konseling akan diukur dengan menggunakan instrumen yang diberikan kepada guru Bimbingan dan Konseling sebelum dan setelah pelatihan. Hal ini dilakukan untuk mengetahui perubahan pemahaman guru Bimbingan dan Konseling setelah diberikan pelatihan. Setelah lebih dari 100 menit materi diberikan. Ada peningkatan pemahaman tentang teori LTCC yang cukup signifikan dari para guru BK. Saran yang disampaikan adalah pemberian pelatihan berupa skill penerapan LTCC di sekolah agaknya perlu diperhatikan. Karena pemahaman tidak cukup untuk bisa menjamin para guru BK dapat mengaplikasikan teori tersebut.
\end{abstract}

Kata kunci: Pelatihan, Learning Theort of Career Counseling

\begin{abstract}
This community service aims to improve the competency of the Junior High School Guidance and Counseling teacher services in the city of Mojokerto. The researcher collaborated with the MGBK Junior High School in the city of Mojokerto. The training that was trained was soft skills in the form of understanding Guidance and Counseling teachers on Services in the career field oriented to the LTCC approach. The target to be achieved after this training is understanding which will ultimately affect counseling services in the career field. The method used in this PKM is conducting training for Guidance and Counseling teachers in a certain time. Guidance and Counseling teacher competencies will be measured by using the instruments given to the Guidance and Counseling teachers before and after training. This is done to determine the change in understanding of Guidance and Counseling teachers after being given training. After more than 100 minutes the material was given. There is a significant increase in understanding of the theory of LTCC from BK teachers. Suggestions conveyed are the provision of training in the form of skills to apply the LTCC at school seems to need attention. Because understanding is not enough to be able to guarantee BK teachers can apply the theory.
\end{abstract}

Keywords: Community Service, Learning Theory of Career Counseling, Counselor

Correspondence author: Evi Winingsih, eviwiningsih@unesa.ac.id, Surabaya, Indonesia (i) (s)

This work is licensed under a CC-BY-NC 


\section{PENDAHULUAN}

Kegiatan ini dimulai dengan melakukan analisis kebutuhan terhadap guru Bimbingan dan Konseling di Kota Mojokerto. Tahap analisis kebutuhan menjadi tahap yang sangat urgent dalam rencana pemberian pelatihan (Irianto, 2001). Berdasarkan data yang didapatkan oleh peneliti, ada beberapa permasalahan yang dihadapi oleh guru Bimbingan dan Konseling di Kota Mojokerto yakni; (1) kurang optimalnya pelayanan BK SMP di Mojokerto yang berorientasi pada teori atau pendekatan tertentu; (2) kurang optimalnya pelayanan guru BK SMP di Mojokerto di Bidang Karier; (3) belum optimalnya guru BK SMP di Mojokerto dalam memberikan pelayanan peminatan karier sesuai bakat dan minat siswa.

Kurang optimalnya pelayanan BK SMP di Mojokerto yang berorientasi pada teori atau pendekatan tertentu. Hal ini diasumsikan terjadi karena guru Bimbingan dan Konseling belum bisa menggunakan satu strategi khusus (yang berorientasi pada teori tertentu) untuk membantu siswa/konseli dalam menyelesaikan permasalahan. Guru Bimbingan dan Konseling masih menggunakan cara konvensional seperti; pemberian nasehat atau sekedar punishment dan reinforcement yang masih dipertanyakan ketepatan dalam penggunaannya. Ada banyak hal yang menyebabkan guru Bimbingan dan Konseling belum bisa optimal melakukan konseling dengan pendekatan tertentu diantaranya: kurangnya updating informasi tentang teeori yang sedang berkembang, kurang terampil dalam memahami dan mempraktikkan, asumsi bahwa menggunakan sebuah teori itu lebih sulit dan rumit, dan sebagainya.

Permasalahan kedua yang dihadapi adalah kurang optimalnya pelayanan guru BK SMP di Mojokerto di Bidang Karier. Kurikulum 2013 menekankan pada peminatan siswa. Siswa pada dasarnya baik dan memiliki potensi yang berbeda sehingga perlu diarahkan pada potensi yang mereka miliki. Layanan peminatan menjadi salah satu sarana untuk menemukan potensi siswa dan mengarahkan pada karier yang tepat. Di kota Mojokerto telah diberikan layanan peminatan, namun masih belum dilaksanakan dengan optimal. Hal ini terlihat adanya siswa yang masih bingung dalam menentukan pilihan jurusan sekolah, sebagian besar siswa juga belum memiliki pemahaman yang konkrit tentang profesi dari pilihan jurusan di sekolah SMK.

Permasalahan ketiga yakni belum optimalnya guru BK SMP di Mojokerto dalam memberikan pelayanan peminatan karier sesuai bakat dan minat siswa. Setiap individu memiliki bakat, namun tidak semua individu memiliki hobi, minat dan kecenderungan untuk meningkatkan bakatnya menjadi sebuah profesi yang profesional. Hal ini diakibatkan karena kurangnya pemberian informasi dan penggalian bakat minat siswa yang dilakukan oleh guru Bimbingan dan Konseling.

Pada hakikatnya siswa membutuhkan perencanaan karier untuk masa depannya. Mereka membutuhkan orang lain untuk membantu masalah penyesuaian dan situasional dan gangguan, seperti masalah perkawinan dan keluarga, difusi identitas, pilihan karir, manajemen kemarahan, kesepian (Conyne, 2004).

Dari permasalahan di atas pengusul bersama mitra menyimpulkan bahwa kurang optimalnya pelayanan Bimbingan dan Konseling di Kota Mojokerto diakibatkan karena kurangnya pemahaman guru Bimbingan dan Konseling terkait pelaksanaan pelayanan bidang karier. Dari kesepakatan kedua belah pihak maka didapatkan kesepakatan untuk memberikan pelatihan kepada guru Bimbingan dan Konseling di kota Mojokerto tentang Konseling Karier. Peaksanaan pelatihan konseling karier dengan pendekatan LTCC dilaksanakan pada Rabu, 15 Agustus 2018 di SMP Negeri 1 Kota Mojokerto. 
Berdasarkan studi yang berorientasi psikologis pilihan karier memberi penekanan utama pada karakteristik kepribadian yang menjadi predisposisi seorang individu untuk mencari karir dari tipe yang diberikan (Brown Duane, 2002). Manusia akan cenderung memilih karier berdasarkan pemahaman terhadap dirinya. Kesiapan kerja merujuk pada keseluruhan kondisi individu yang meliputi kematangan fisik, mental, dan pengalaman serta adanya kemauan dan kemampuan untuk melaksanakan suatu pekerjaan atau kegiatan (Datadiwa \& Widodo, 2015).

Target yang akan dicapai dari pengabdian ini adalah meningkatnya pemahaman guru Bimbingan dan Konseling Kota Mojokerto tentang konseling karier khususnya pendekatan LTCC. Pencapaian target akan diketahui dari nilai angket yang telah disebarkan kepada peserta. Penggunaan angket akan lebih memudahkan dalam perhitungan terhdap nilai pasti perubahan pemahaman yang akan dicapai (Martono, 2010). Jenis luaran dari pelaksanaan pelatihan ini adalah pengembangan softskills atau berbentuk jasa. Softskills guru Bimbingan dan Konseling yang memahami dan melaksanakan pelayanan Bimbingan dan Konseling dengan pendekatan LTCC. Tujuan dari konseling karier adalah untuk membantu klien belajar mengambil tindakan untuk mencapai karier dan kehidupan pribadi yang lebih memuaskan — bukan untuk membuat keputusan karier tunggal (Coleman \& Yeh, 2011; Krumboltz, 2009).

Pemilihan materi LTCC dipilih bukan tanpa sebuah alasan. LTCC menekankan pada pengalaman belajar individu yang unik yang terjadi sepanjang hayat dan menjadi dasar dalam pilihan karir individu. Ada lima (5) hal pokok yang mendasari individu tidak mampu memilih karier berdasar LTCC yakni: (1) gagal dalam mengatasi masalah yang ada, (2) gagal dalam menggunakan usaha yang dibutuhkan untuk membuat keputusan, (3) menghilangkan potensi yang justru dibutuhkan, (4) memilih pilihan yang tidak tepat, dan (5) baper terlalu lama dan cemas yang berlebihan (Krumboltz, Foley, \& Cotter, 2013).

\section{METODE PELAKSANAAN}

PKM dilaksanakan di SMP Negeri 1 Mojokerto. Lokasi ini dipilih berdasarkan kesepakatan kedua belah pihak. Selama proses pelatihan pelaksana mengukur pemahaman peserta terhadap materi yang disampaikan dan penilaian peserta terhadap pelatihan dari aspek kegunaan dan kepatutan materi pelatihan. Kesesuaain ini akan meningkatkan proses perubahan atau tujuan yang akan dicapai (Sanjaya, 2016; Yusuf, 2016). Pengumpulan data melalui angket keterpahaman materi dan angket kelayakan palatihan. Angket yang dipakai untuk menguji keterpahaman materi adalah angket terbuka. Pertanyaan terbuka memungkinkan responden menjawab bebas dan seluasluasnya terhadap pertanyaan namun dalam pertanyaan tertutup, responden hanya diberi kesempatan memilih jawaban yang tersedia (Pujihastuti, 2010).

Peserta dalam pelatihan ini sejumlah tiga puluh lima (35) orang guru Sekolah Menegah Pertama di Mojokerto. Perlengkapan yang dibutuhkan selama proses kegiatan disiapkan oleh pelaksana dan pihak mitra. Diantara yang disiapkan oleh pihak mitra adalah: tempat kegiatan, konsumsi, LCD, kabel olor, meja dan kursi. Sedangkan yang disiapkan oleh pelaksana adalah; laptop, camera, dan materi. 


\section{HASIL DAN PEMBAHASAN}

Target utama dari Pengabdian pada masyarakat adalah peningkatan pemahaman guru BK tentang konseling karier khususnya teori LTCC. Teori LTCC berbeda dengan trait and faktor yang lebih menekan pada hal yang static pada diri individu (Krumboltz, 1996). Skor rata-rata guru BK setelah diberikan pelatihan LTCC adalah 7,7. Hal ini mengindikasikan bahwa guru BK memiliki tingkat pemahaman yang sangat baik tentang topik dan materi yang disampaikan oleh pelaksana. Selain itu, skor tersebut mengindikasikan bahwa guru BK mampu melakukan refleksi diri terhadap program BK pada bidang karier. Guru BK juga mampu merencakan perbaikan terhadap pelayanan BK karier. Berikut ini adalah tabel ketepahaman materi pelatihan;

Tabel 1 Pemahaman Peserta Terhadap Materi Pelatihan

\begin{tabular}{|c|c|c|c|}
\hline No & Nama Peserta & $\begin{array}{l}\text { Skor } \\
(1-10)\end{array}$ & Keterangan \\
\hline 1 & Desi Umilawati & 10 & Peserta mampu memahami dan menjelaskan kembali topik materi dan \\
\hline 2 & Devi Akta Pratiwi & 10 & isi materi tentang karier yang mempengaruhi individu yang telah \\
\hline 3 & Kharisma Cahyandini & 10 & disampaiakan dan menjelaskan dengan contoh. Mampu merefleksi \\
\hline 4 & Liliek Martini & 10 & $\begin{array}{l}\text { kelemahan dan tindak lanjut untuk pelayanan BK karier di sekolahnya } \\
\text { secara konkrit. }\end{array}$ \\
\hline 5 & Idham Sinarisyah & 9.5 & Peserta mampu memahami dan menjelaskan kembali topik materi dan \\
\hline 6 & Yang Gustida & 9.5 & isi materi tentang karier yang mempengaruhi individu. Mampu \\
\hline 7 & Septri W & 9.5 & $\begin{array}{l}\text { menjelaskan sebagian dengan contoh. Mampu merefleksi kelemahan } \\
\text { dan tindak lanjut untuk pelayanan BK karier di sekolahnya dengan baik. }\end{array}$ \\
\hline 8 & Siti Cholifah & 9 & Peserta mampu memahami dan menjelaskan kembali topik materi dan \\
\hline 9 & Kotimatul Yuroh & 9 & isi materi tentang karier yang mempengaruhi individu yang telah \\
\hline 10 & Umi Fauziah & 9 & $\begin{array}{l}\text { disampaiakan dan menjelaskan dengan contoh. Mampu merefleksi } \\
\text { kelemahan dan tindak lanjut untuk pelayanan BK karier di sekolahnya. }\end{array}$ \\
\hline 11 & Erin $S$ & 8.5 & Peserta mampu menjelaskan kembali topik materi dan isi materi tentang \\
\hline 12 & Tutik Suwarni & 8.5 & karier yang mempengaruhi individu yang telah disampaiakan. Peserta \\
\hline 13 & Jesica Ch & 8.5 & mampu melakukan refleksi diri dengan baik dan merencanaan perbaikan \\
\hline 14 & Khotimah & 8.5 & $\begin{array}{l}\text { dari pelayanan BK bidang Karier. Sebagian mampu menjelaskan } \\
\text { dengan contoh. }\end{array}$ \\
\hline 15 & Dian Andra R.H & 8 & Peserta mampu menjelaskan kembali topik materi dan isi materi tentang \\
\hline 16 & Cicilia Hardiani & 8 & karier yang mempengaruhi individu yang telah disampaiakan. Peserta \\
\hline 17 & Rusli Kustiowati & 8 & mampu melakukan refleksi diri dengan baik dan merencanaan perbaikan \\
\hline 18 & Atik Febriatiningtyas & 8 & dari pelayanan BK bidang Karier. \\
\hline 19 & Wiwik Dwi Purwanti & 7.5 & Peserta mampu menjelaskan kembali topik materi dan isi materi tentang \\
\hline 20 & Purwaningrum & 7.5 & karier yang mempengaruhi individu yang telah disampaiakan. Namun \\
\hline 21 & Latifah Kartikawati & 7.5 & peserta masih kurang mampu menjelaskan dengan contoh. Peserta \\
\hline 22 & Wigati P & 7.5 & $\begin{array}{l}\text { memiliki gambaran apa yang akan diperbaiki untuk pelayanan karier di } \\
\text { sekolah cukup baik. }\end{array}$ \\
\hline 23 & Nurul Hidaya & 7 & Peserta mampu menjelaskan kembali topik materi dan isi materi tentang \\
\hline 24 & Lestari Wilujeng & 7 & karier yang mempengaruhi individu yang telah disampaiakan. Namun \\
\hline 25 & Juniar Dwi A.P & 7 & $\begin{array}{l}\text { peserta masih kurang mampu menjelaskan dengan contoh. Secara } \\
\text { umum peserta memiliki gambaran apa yang akan diperbaiki untuk } \\
\text { pelayanan karier di sekolah }\end{array}$ \\
\hline 26 & $\begin{array}{l}\text { Fitthriyatul } \\
\text { Kholqiyah }\end{array}$ & 6.5 & $\begin{array}{l}\text { Mampu menebutkan factor dengan denan baik tanpa penjelasan, kurang } \\
\text { tepat menyebutkan topik materi. Secara umum mampu melakukan } \\
\text { reflesi diri dan perbaikan untuk pelayanan BK Karier }\end{array}$ \\
\hline 27 & Lusia & 6 & Peserta mampu menjelaskan kembali topik materi dan isi materi tentang \\
\hline 28 & Wahjuni Sri Redjeki & 6 & karier yang mempengaruhi individu yang telah disampaiakan. Peserta \\
\hline 29 & Moch. Romli & 6 & memiliki denial untuk melakukan refleksi terhadap programnya. \\
\hline 30 & Sri Widji & 6 & \\
\hline 31 & Endah Budiarti & 6 & \\
\hline 32 & Devi Anjurita Silalahi & 5.5 & Peserta mampu menjelaskan kembali topik materi dan isi materi tentang \\
\hline 33 & Sri Syharti & 5.5 & $\begin{array}{l}\text { karier yang mempengaruhi individu yang telah disampaiakan. Namun } \\
\text { peserta masih kurang mampu menjelaskan dengan contoh. Peserta } \\
\text { memiliki denial untuk melakukan refleksi terhadap programnya. }\end{array}$ \\
\hline
\end{tabular}




\begin{tabular}{|c|c|c|c|}
\hline 34 & $\begin{array}{l}\text { Purwanti } \\
\text { Agustianingsih }\end{array}$ & 5 & $\begin{array}{l}\text { Mampu menyebutkan topik dan factor perkembangan karier tanpa } \\
\text { penjelasan. Kurang mampu melakukan refleksi diri. }\end{array}$ \\
\hline \multirow[t]{2}{*}{35} & Khoiriyah & 5 & \\
\hline & Skor Rata-rata & 7.7 & $\begin{array}{l}1 \text { sd } 2,5=\text { Tidak memahami topik materi dan tidak mampu melakukan } \\
\text { refleksi dan perbaikan program pelayanan BK Karier } \\
2,6 \text { sd } 5=\text { Kurang memahami topik materi dan tidak mampu } \\
\text { melakukan refleksi dan perbaikan program pelayanan BK Karier } \\
5,1 \text { sd } 7,5=\text { Memahami topik materi dan tidak mampu melakukan } \\
\text { refleksi dan perbaikan program pelayanan BK Karier } \\
7,6 \text { sd } 10=\text { sanagat memahami topik materi dan tidak mampu } \\
\text { melakukan refleksi dan perbaikan program pelayanan BK Karier }\end{array}$ \\
\hline
\end{tabular}

Selain mengukur keterpahaman materi pelaksana juga mengukur kebergunaan dan kepatutan pelaksanaan PKM kepada peserta. Skor rata-rata peserta 3,35; skor rata rata kegunaan 3,36; skor rata-rata kepatutan 3,24. Skor tersebut mengindikasi bahwa pelatihan yang diberikan sangat penting dan memiliki kebermanfaatan yang sangat baik. Dari sisi kepatutan pelatihan ini sangat patut diberikan untuk guru BK SMP di Mojokerto. Berikut ini ada detail table kepatutan dan kegunaan kegiatan;

Tabel 2 Skala Penilaian Pelatihan Konseling LTCC

\begin{tabular}{|c|c|c|c|c|c|c|c|c|c|}
\hline \multirow[t]{3}{*}{ No } & \multicolumn{8}{|c|}{ Aspek } & \multirow{3}{*}{$\begin{array}{l}\text { Skor rata-rata } \\
\text { perindividu }\end{array}$} \\
\hline & \multicolumn{5}{|c|}{ Kegunaan } & \multicolumn{3}{|c|}{ Kepatutan } & \\
\hline & 1 & 2 & 3 & 4 & 5 & 6 & 7 & 8 & \\
\hline 1 & 4 & 4 & 4 & 4 & 3 & 3 & 3 & 3 & 3,50 \\
\hline 2 & 3 & 3 & 4 & 3 & 3 & 4 & 3 & 4 & 3,38 \\
\hline 3 & 3 & 4 & 3 & 3 & 3 & 3 & 3 & 3 & 3,13 \\
\hline 4 & 4 & 4 & 3 & 3 & 3 & 3 & 3 & 3 & 3,25 \\
\hline 5 & 3 & 3 & 3 & 3 & 3 & 3 & 3 & 3 & 3,00 \\
\hline 6 & 4 & 3 & 3 & 3 & 4 & 4 & 3 & 3 & 3,38 \\
\hline 7 & 3 & 4 & 4 & 3 & 3 & 3 & 3 & 4 & 3,38 \\
\hline 8 & 4 & 4 & 3 & 3 & 4 & 3 & 3 & 3 & 3,38 \\
\hline 9 & 3 & 4 & 4 & 3 & 4 & 3 & 3 & 3 & 3,38 \\
\hline 10 & 3 & 3 & 3 & 3 & 3 & 3 & 3 & 3 & 3,00 \\
\hline 11 & 4 & 4 & 3 & 3 & 4 & 3 & 3 & 3 & 3,38 \\
\hline 12 & 4 & 4 & 4 & 4 & 4 & 3 & 3 & 3 & 3,63 \\
\hline 13 & 3 & 3 & 4 & 3 & 3 & 4 & 4 & 4 & 3,50 \\
\hline 14 & 4 & 4 & 4 & 3 & 4 & 4 & 3 & 4 & 3,75 \\
\hline 15 & 4 & 3 & 3 & 3 & 3 & 3 & 3 & 3 & 3,13 \\
\hline 16 & 3 & 4 & 3 & 3 & 3 & 3 & 3 & 3 & 3,13 \\
\hline 17 & 3 & 3 & 3 & 3 & 3 & 3 & 3 & 3 & 3,00 \\
\hline 18 & 3 & 3 & 3 & 3 & 3 & 4 & 3 & 3 & 3,13 \\
\hline 19 & 3 & 3 & 3 & 3 & 3 & 3 & 3 & 3 & 3,00 \\
\hline 20 & 3 & 3 & 3 & 3 & 3 & 3 & 3 & 3 & 3,00 \\
\hline 21 & 3 & 3 & 3 & 3 & 3 & 3 & 3 & 4 & 3,13 \\
\hline 22 & 4 & 4 & 4 & 3 & 4 & 4 & 3 & 4 & 3,75 \\
\hline 23 & 4 & 4 & 4 & 4 & 4 & 4 & 4 & 4 & 4,00 \\
\hline 24 & 4 & 4 & 3 & 4 & 3 & 3 & 3 & 3 & 3,38 \\
\hline 25 & 4 & 4 & 4 & 3 & 4 & 4 & 3 & 4 & 3,75 \\
\hline 26 & 3 & 3 & 3 & 3 & 3 & 3 & 3 & 3 & 3,00 \\
\hline
\end{tabular}




\begin{tabular}{|c|c|c|c|c|c|c|c|c|c|}
\hline 27 & 3 & 3 & 3 & 3 & 3 & 3 & 3 & 3 & 3,00 \\
\hline 28 & 3 & 4 & 3 & 3 & 4 & 3 & 4 & 3 & 3,38 \\
\hline 29 & 4 & 4 & 4 & 3 & 4 & 4 & 3 & 4 & 3,75 \\
\hline 30 & 3 & 4 & 3 & 4 & 3 & 4 & 3 & 3 & 3,38 \\
\hline 31 & 3 & 3 & 3 & 3 & 3 & 3 & 3 & 3 & 3,00 \\
\hline 32 & 3 & 3 & 3 & 3 & 3 & 4 & 3 & 3 & 3,13 \\
\hline 33 & 3 & 3 & 4 & 3 & 4 & 3 & 3 & 3 & 3,25 \\
\hline \multirow[t]{5}{*}{34} & 4 & 4 & 4 & 3 & 3 & 4 & 3 & 3 & 3,50 \\
\hline & 3,41 & 3,53 & 3,38 & 3,15 & 3,35 & 3,35 & 3,09 & 3,26 & 3,35 \\
\hline & \multicolumn{9}{|c|}{ rata-rata per-item } \\
\hline & \multicolumn{5}{|l|}{3,36} & \multicolumn{4}{|l|}{3,24} \\
\hline & \multicolumn{5}{|c|}{ rata-rata skor kegunaan } & \multicolumn{4}{|c|}{ rata-rata skor kepatutan } \\
\hline
\end{tabular}

Membangun identitas karier dalam bentuk yang berorientasi masa depan, sangat penting dengan membantu peserta didik melalui tahapan pembelajaran kognitif. LTCC memberikan bantuan dialog tentang pengalaman konkret yang bertujuan untuk memperhatikan emosi dan memperluas dan memperdalam apa yang diungkapkan dan karier yang diinginkan oleh peserta didik (Meijers \& Lengelle, 2015). Peningkatan keterpahaman guru BK SMP sebagai peserta pelatihan tidak terlepas karena teori ini mudah di aplikasikan oleh peserta di sekolah. Tahapan dalam LTCC di akronimkan menjadi DECIDES. Langkah tersebut adalah: (1) Mendefinisikan masalah (define the problem); (2) Membuat rencana kegiatan (establish an action plan); (3) Mengklasifikasi nilai (clarify values); (4) Mengidentifikasi pilihan (indentity alternatives); (5) Mengetahui dampak-dampak masalah (discover probable outcomes); (6) Mengeliminasi beberapa alternatif secara sistematis (eliminate alternatives systematically); (7) Mulai bertindak (start action) (Krumboltz, 1996).

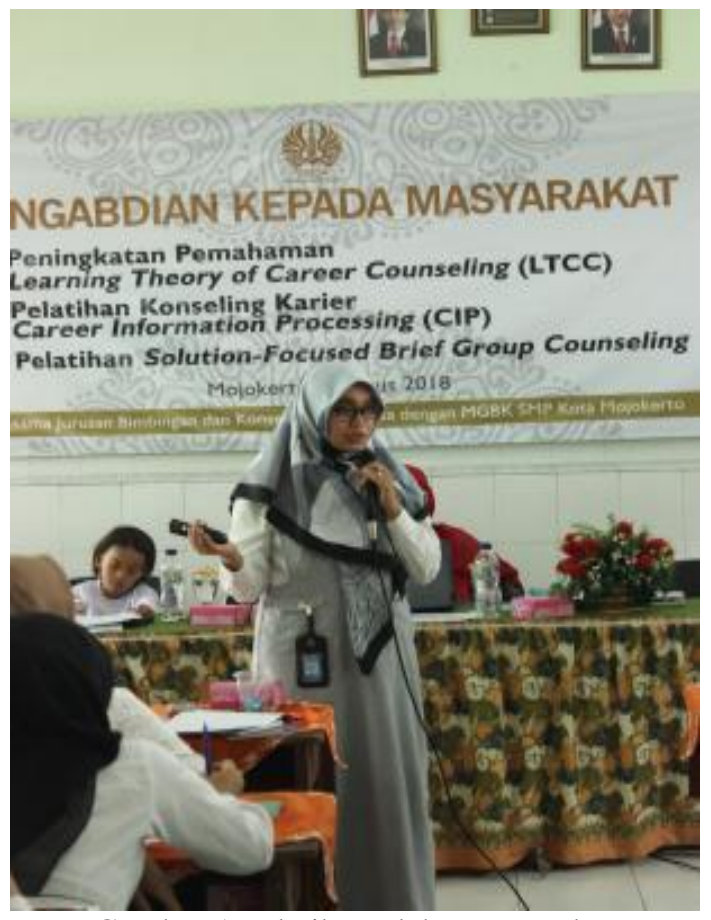

Gambar 1 Pelatihan oleh Narasumber 


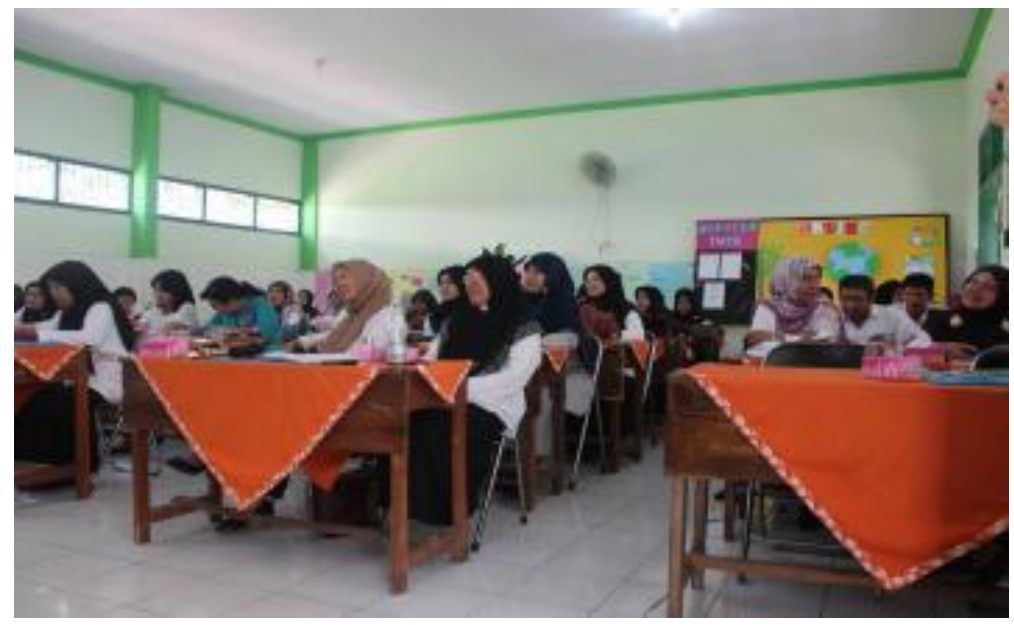

Gambar 2 Peserta Pelatihan

Gambar di atas merupakan dapat menggambarkan antusiasme guru dalam mengikuti pelatihan Learning Theory of Career Counseling. Kegiatan tersebut disampaikan oleh narasumber selama kurang lebih 100 menit. Adanya pemahaman guru Bimbingan dan Konseling yang cukup tinggi mengindikasikan bahwa pelatihan yang diselengarakan di Mojokerto berjalan sesuai dengan harapan pelaksana.

\section{SIMPULAN}

Secara umum kegiatan pengabdian kepada masyarakat berjalan dengan baik. Memiliki kebermanfaatan terhadap pemahaman peserta tentang konseling karier. Hal ini tentu terlihat dari antusiasme guru BK dalam proses pelaksanaan kegiatan, diskusi guru BK dan pemateri saat sesi tanya jawab dan umpan balik yang diberikan setelah proses penyampaian materi.

Guru BK mampu meningkatkan pemahamannya tentang faktor yang memengaruhi perkembangan karier individu. Angket yang telah diberikan dalam rangka pemberian umpan balik menunjukkan bahwa peserta memiliki peningkatan pemahan teori LTCC yang sebelumnya guru BK belum pernah menerapkan teori ini. Ada juga sebagian yang menyebutkan bahwa pernah melakukan pendekatan tersebut, namun tidak tahu apa teori yang dipakai. Pada hakikatnya kegiatan ini berjalan dengan lancar dan sesuai dengan target yang telah di tetapkan di awal kegiatan.

\section{UCAPAN TERIMA KASIH}

Terima kasih kami sampaikan kepada pihak yang telah membantu terselenggarakannya Pengabdian Kepada Masyarakat ini. Kegiatan ini tidak akan berjalan dengan sukses tanpa bantuan dari jurusan BK FIP Unesa yang telah mendanai kegiatan ini, berserta para TIM yang telah menyukseskan Pengabdian Kepada Masyarakat ini. TIM Musyawarah Guru Bimbingan dan Konseling (MGBK) SMP Kota Mojokerto yang telah menyediakan tempat acara dan berbagai kebutuhan yang dibutuhkan. Terima kasih atas kerjasama yang luar biasa. 


\section{DAFTAR PUSTAKA}

Brown Duane. (2002). Caree Choice and Development (4th ed.). New York: Jossey-Bass.

Coleman, H. L. K., \& Yeh, C. (2011). Handbook of school counseling. Routledge.

Conyne, R. K. (2004). Preventive counseling: Helping people to become empowered in systems and settings. Routledge.

Datadiwa, D., \& Widodo, J. (2015). Analisis Faktor-faktor yang Mempengaruhi Kesiapan Kerja Siswa SMK Negeri 1 Warureja Tahun 2014. Economic Education Analysis Journal, 4(1).

Irianto, J. (2001). Prinsip-prinsip dasar manajemen pelatihan. Surabaya: Insan Cendekia.

Krumboltz. (1996). A Learning Theory of Career Counseling. US: Davies-Black Publishing.

Krumboltz, J. D. (2009). The happenstance learning theory. Journal of Career Assessment, 17(2), 135-154.

Krumboltz, J. D., Foley, P. F., \& Cotter, E. W. (2013). Applying the happenstance learning theory to involuntary career transitions. The Career Development Quarterly, 61(1), 15-26.

Meijers, F., \& Lengelle, R. (2015). 5. CAREER LEARNING. Career Assessment: Qualitative Approaches, 41.

Pujihastuti, I. (2010). Prinsip Penulisan Kuesioner Penelitian. CEFARS: Jurnal Agribisnis Dan Pengembangan Wilayah, 2(1), 43-56.

Sanjaya, D. R. H. W. (2016). Penelitian tindakan kelas. Prenada Media.

Yusuf, A. M. (2016). Metode penelitian kuantitatif, kualitatif \& penelitian gabungan. Prenada Media. 